\title{
Serine Hydroxymethyltransferase and Glycine Cleavage Enzyme from the Cyanogenic Bacterium Chromobacterium violaceum
}

\author{
By SORAYA P. SHIRAZI-BEECHEY AND \\ CHRISTOPHER J. KNOWLES* \\ Biological Laboratory, University of Kent, Canterbury, Kent CT2 7NJ, UK
}

(Received 21 September 1983)

\begin{abstract}
Chromobacterium violaceum forms cyanide as a secondary metabolite with glycine as the precursor and methionine as a stimulator. As the metabolism of glycine and methionine are interrelated by the provision of carbon-one units for the tetrahydrofolate pool by the activities of serine hydroxymethyltransferase (SHMT) and glycine cleavage enzyme (GCE), we have investigated the regulation of formation and activity of these enzymes by $C$. violaceum. The synthesis of SHMT was unaffected by growth under conditions of high cyanogenesis (on a medium containing glutamate, glycine and methionine) or low cyanogenesis (on glutamate alone), nor was its synthesis affected by addition of potential end-products of carbon-one metabolism to the growth medium. The activity of GCE was very low, less than $1 \%$ of the activity of SHMT, irrespective of the growth conditions. This suggests that nearly all the carbonone units for the tetrahydrofolate pool are supplied by the activity of SHMT; this could lead to excess formation of glycine and might explain the role of cyanogenesis. The activity of SHMT was competitively inhibited by glycine and cysteine.
\end{abstract}

\section{INTRODUCTION}

Cyanide is formed as a secondary metabolite by several bacteria (Knowles, 1976; Castric, 1981). It is synthesized from glycine in a process stimulated by L-methionine (Michaels \& Corpe, 1965; Wissing, 1968; Castric, 1977; Rodgers \& Knowles, 1978). The properties of the cyanide synthase have been examined in Pseudomonas aeruginosa, a Pseudomonas species and Chromobacterium violaceum (Castric et al., 1981; Wissing \& Andersen, 1981 ; Bunch \& Knowles, 1982). In $C$. violaceum cyanide is rapidly degraded, principally to $\beta$-cyanoalanine via a synthase that can be inhibited by methionine (Rodgers \& Knowles, 1978; Rodgers, 1981, 1982).

The reasons for microbial secondary metabolism have not been resolved, though it is generally supposed that it is due to insufficiently efficient regulation of primary metabolism, particularly at branch points (Demain et al., 1979; Rose, 1979). The production of secondary metabolites could have evolved as an overflow mechanism for controlling complex primary metabolic pathways (Malik, 1980; Zähner, 1977).

As part of a study of the relationship of primary and secondary metabolism of $C$. violaceum we have examined the synthesis and regulatory properties of serine hydroxymethyltransferase (SHMT) and synthesis of glycine cleavage enzyme (GCE). This is because the primary metabolism of glycine (the precursor of cyanide) and methionine (the stimulator of cyanogenesis) is linked by SHMT and GCE via the provision of carbon-one units of the tetrahydrofolate pool and hence as the source of methyl groups for methionine formation.

\section{METHODS}

Organisms and growth conditions. Chromobacterium violaceum NCIB 9131 was grown on minimal salts medium consisting of $\mathrm{M}-9$ salts (Miller, 1972) with $\mathrm{NH}_{4} \mathrm{Cl}$ omitted, plus $1 \mathrm{ml}$ trace metals $\mathrm{I}^{-1}$ (Bauchop \& Elsden, 1960) with the $\mathrm{Fe}^{2+}$ concentration raised to $30 \mu \mathrm{M}$ to enhance cyanogenesis (Rodgers \& Knowles, 1978). L-Glutamate

Abbreviations: GCE, glycine cleavage enzyme (glycine synthase; EC 2.1.2.10); SHMT, serine hydroxymethyltransferase (EC 2.1.2.1) 
(10 mM) was used as the source of carbon and nitrogen. Where indicated, 0.5 or $2 \mathrm{mM}-\mathrm{L}-\mathrm{methionine}$ and/or $2 \mathrm{mM}-$ glycine were added to the medium. Other additions to the medium (all at $2 \mathrm{mM}$ ) are indicated in the text. Growth was in $100 \mathrm{ml}$ medium in $250 \mathrm{ml}$ conical flasks, or in $500 \mathrm{ml}$ medium in $2-1$ conical flasks; incubation was at $30^{\circ} \mathrm{C}$ in a gyrotary shaker (250 r.p.m.). A $1 \%(\mathrm{v} / \mathrm{v})$ inoculum of a $24 \mathrm{~h}$ stationary phase culture grown on medium containing $10 \mathrm{mM}$-glutamate was used to indicate experimental flasks.

Escherichia coli K 12 (strain B SPAO, University of Warwick culture collection) was supplied by Dr C. Dow and used as described below.

Preparation of extracts. Chromobacterium violaceum was routinely harvested $11 \mathrm{~h}$ after inoculation, i.e. at the end of exponential growth and the time of optimal cyanogenesis (Rodgers \& Knowles, 1978; Bunch \& Knowles, 1982). Bacteria were harvested by centrifuging at $25000 \mathrm{~g}$ for $10 \mathrm{~min}$ at $4^{\circ} \mathrm{C}$ and washed in ice-cold $50 \mathrm{mM}-$ $\mathrm{Na}_{2} \mathrm{HPO}_{4} / \mathrm{KH}_{2} \mathrm{PO}_{4}$ buffer (pH 7.5). The bacteria were resuspended to about $1.5 \%(\mathrm{v} / \mathrm{v})$ of the growth volume in $75 \mathrm{mM}-\mathrm{KH}_{2} \mathrm{PO}_{4} / \mathrm{K}_{2} \mathrm{HPO}_{4}$ buffer $(\mathrm{pH} 7 \cdot 4)$. Bacteria were disrupted by sonicating $\left(3 \times 20 \mathrm{~s}\right.$ at $4{ }^{\circ} \mathrm{C}, \mathrm{MSE}$ sonicator model $150 \mathrm{~W}$ ). Whole cells and debris were removed by centrifuging at $10000 \mathrm{~g}$ for $10 \mathrm{~min}$ at $4^{\circ} \mathrm{C}$. The extract was separated into particulate and supernatant fractions at $150000 \mathrm{~g}$ for $90 \mathrm{~min}$ at $4^{\circ} \mathrm{C}$. The particulate fraction was rinsed with 75 mM-potassium phosphate buffer (pH 7.4) and resuspended in the same buffer. The top half of the supernatant fraction was routinely retained. It was dialysed for $16 \mathrm{~h}$ at $4^{\circ} \mathrm{C}$ against four changes of icecold $75 \mathrm{~mm}$-potassium phosphate buffer (pH 7.4). The dialysed supernatant fraction was either used directly or stored at $-20^{\circ} \mathrm{C}$ for up to 3 weeks. In the latter case no change in SHMT activity was observed.

$E$. coli was grown on $\mathrm{M}-9$ salts plus glucose and $\mathrm{NH}_{4} \mathrm{Cl}$ and harvested in the stationary phase, $16 \mathrm{~h}$ after inoculation. Cell-free extracts were prepared as described for $C$. violaceum except that 50 mm-potassium phosphate buffer (pH 7.0) was used at all stages.

Determination of enzyme activities. SHMT was assayed by the method of Folk \& Berg (1970) with slight modifications. The reaction mixture $(0.24 \mathrm{ml})$ contained $50 \mathrm{mM}$-Tris/HCl buffer $(\mathrm{pH} 8.5), 25 \mu \mathrm{M}$-pyridoxal phosphate, $1.8 \mathrm{mM}$-dl-L-tetrahydrofolate, $25 \mathrm{mM}$ - $\beta$-mercaptoethanol, and 0.1 or $1 \mathrm{mM} \mathrm{L-}[\mathrm{U}-1+\mathrm{C}]$ serine $[0 \cdot 143 \mu \mathrm{Ci}$ $(5.29 \mathrm{kBq}) \mu \mathrm{mol}^{-1}$ ]; the final $\mathrm{pH}$ was 8.3. The mixture was incubated for $5 \mathrm{~min}$ at $37^{\circ} \mathrm{C}$ and the reaction initiated by addition of 10 to $30 \mu \mathrm{l}$ supernatant fraction ( $50 \mu \mathrm{g}$ protein). After $10 \mathrm{~min}$ the reaction was terminated by addition of $0.3 \mathrm{ml}$ ice-cold $1 \mathrm{M}$-sodium acetate (pH 4.5). The mixture was cooled in ice, and $0.2 \mathrm{ml} 0.1 \mathrm{M}$ formaldehyde and $0.3 \mathrm{ml} \mathrm{0.4} \mathrm{M-dimedon} \mathrm{[5,5-dimethyl-1,3-cyclohexanedione} \mathrm{in} 50 \%(\mathrm{v} / \mathrm{v})$ ethanol] were added. The mixture was heated for $5 \mathrm{~min}$ at $100^{\circ} \mathrm{C}$ and then cooled for $5 \mathrm{~min}$ in ice. The contents were filtered through a $25 \mathrm{~mm}$ Whatman GF/C glass microfibre filter and the precipitate washed with $30 \mathrm{ml}$ cold water. The filter paper was dried overnight at $35^{\circ} \mathrm{C}$ and placed in a vial containing $4 \mathrm{ml}$ scintillation fluid $(4 \mathrm{~g}$ PPO and $100 \mathrm{mg}$ POPOP in 11 toluene) and counted in a scintillation counter. SHMT activity is given as nmol formaldehyde formed min $^{-1}$ (mg protein) $)^{-1}$.

GCE was assayed by the release of ${ }^{14} \mathrm{CO}_{2}$ from $\left[1-{ }^{14} \mathrm{Clglycine}\right.$ (Moore et al., 1977; Kelvraa, 1979). The reaction was carried out in $50 \mathrm{ml}$ conical flasks, each fitted with a centre well and a serum capped (Suba-Seal; Astell Laboratory Service Co., Catford, London, UK) side arm. The reaction mixture $(2.5 \mathrm{ml})$ in the main compartment contained 50 mM-potassium phosphate buffer (pH 7.0), 1.2 mm-pyridoxal phosphate, 0.32 mm-tetrahydrofolate, $1.2 \mathrm{~mm}$-EDTA, $12 \mathrm{~mm}-\beta$-mercaptoethanol, $1.2 \mathrm{~mm}-\mathrm{NAD}^{+}$and cell-free extract (10 mg protein). The centre well contained $0.2 \mathrm{ml} \mathrm{20} \%(\mathrm{w} / \mathrm{v}) \mathrm{KOH}$ to collect ${ }^{14} \mathrm{CO}_{2}$. The flasks were closed and incubated at $25^{\circ} \mathrm{C}$ for $5 \mathrm{~min}$ with shaking. The reaction was initiated by injecting $[1.14 \mathrm{C}$ glycine $[5 \mathrm{mM}, 0.15 \mu \mathrm{Ci}(5.55 \mathrm{kBq})]$ from a microsyringe via the serum-capped side arm. After $30 \mathrm{~min}$ incubation $0.2 \mathrm{ml} 2.5 \mathrm{M}_{-} \mathrm{H}_{2} \mathrm{SO}_{4}$ was injected to terminate the reaction. The mixture was shaken for a further $60 \mathrm{~min}$ to permit complete transfer of the ${ }^{14} \mathrm{CO}_{2}$ to the $\mathrm{KOH}$. A sample $(0.1 \mathrm{ml})$ was removed from the centre well and added to a vial containing $4 \mathrm{ml}$ of phase combining scintillation fluid (PCS) and counted in a scintillation counter. GCE activity is given as nmol $\mathrm{CO}_{2}$ formed min ${ }^{-1}$ (mg protein) ${ }^{-1}$.

Other assays. Protein was assayed by the Lowry method using bovine serum albumin as the standard. Cyanide was assayed by the method of Lambert et al. (1975). Growth was determined by the turbidity at $750 \mathrm{~nm}$ using $10 \mathrm{~mm}$ cuvettes.

Chemicals. Glycine, L-methionine and glutamate were obtained from Sigma. PCS was from Amersham Corp., Arlington Heights, Ill., USA. [1-14 C]Glycine and [U-14 C]serine were from Amersham. Dimedon, formaldehyde and PPO were from Fisons. POPOP was from Koch-Light Laboratories. Whenever possible, all other reagents were of analytical grade; glass-distilled water was used throughout.

\section{RESULTS}

\section{Serine hydroxymethyltransferase}

SHMT of $C$. violaceum was found to be a soluble enzyme (Table 1); all subsequent experiments were therefore carried out using the high-speed supernatant fraction. As SHMT activity was similar for growth on glutamate plus glycine and methionine (when maximal cyanogenesis 


\section{Table 1. Activity of SHMT in different cellular fractions derived from C. violaceum}

C. violaceum was grown on $10 \mathrm{mM}$-glutamate as the carbon and nitrogen source. Bacteria were harvested $14 \mathrm{~h}$ after inoculation and the cell-free extract and particulate and supernatant fractions obtained as described in Methods. SHMT activity was determined using $1 \mathrm{mM}$-serine as the substrate. The values given are the mean $\pm S D$, with the number of observations in parentheses.

\begin{tabular}{|c|c|c|c|}
\hline Fraction & $\begin{array}{l}\text { Total protein } \\
\text { (mg) }\end{array}$ & 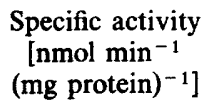 & $\begin{array}{l}\text { Total activity } \\
\left(\text { nmol } \min ^{-1}\right)\end{array}$ \\
\hline $\begin{array}{l}\text { Cell-free extract } \\
\text { Supernatant fraction } \\
\text { Particulate fraction }\end{array}$ & $\begin{array}{r}300 \pm 2(6) \\
63 \pm 1(6) \\
228 \pm 2(6)\end{array}$ & $\begin{array}{l}16 \pm 2(6) \\
62 \pm 4(6) \\
1 \cdot 8 \pm 0.3(6)\end{array}$ & $\begin{array}{r}4800 \\
3906 \\
410\end{array}$ \\
\hline
\end{tabular}

occurred; Rodgers \& Knowles, 1978) or on glutamate (little cyanogenesis), growth on glutamate alone was routinely used. Activity was similar in bacteria harvested in either the midexponential phase ( 6 to $8 \mathrm{~h}$ after inoculation), at the point of maximal cyanogenesis $(11 \mathrm{~h})$ or in the stationary phase $(14 \mathrm{~h})$ for growth on either glutamate or glutamate plus glycine and methionine.

There was no loss of SHMT activity when the supernatant fraction was dialysed overnight at $4{ }^{\circ} \mathrm{C}$ against $75 \mathrm{~mm}$-potassium phosphate buffer $(\mathrm{pH} 7 \cdot 4)$ either in the presence or absence of 2 mM-EDTA. Activity of the supernatant, either dialysed or undialysed, was stable on storage at $4{ }^{\circ} \mathrm{C}$ for $24 \mathrm{~h}$ or for 3 weeks at $-20^{\circ} \mathrm{C}$, but over $90 \%$ of the activity was lost by storage at $4{ }^{\circ} \mathrm{C}$ for $72 \mathrm{~h}$. SHMT activity was unaffected by addition of $2 \mathrm{mM}$-dithiothreitol, $2 \mathrm{mM}$ - $\beta$-mercaptoethanol, $0.5 \mathrm{~mm}-\mathrm{Mg}^{2+}, 0.5 \mathrm{~mm}-\mathrm{Ca}^{2+}$ or $0.5 \mathrm{mM}-\mathrm{Mn}^{2+}$ to the assay mixture.

SHMT had a pH optimum at 8.5 ; there was $90 \%$ of this activity at $\mathrm{pH} 7.6$ and $9 \cdot 1$, and $50 \%$ at pH 7.2 and 9.6. The optimal activity (at $\mathrm{pH} 8.5$ ) was similar in $50 \mathrm{mM}$-Tris/ $\mathrm{HCl}$ buffer, Bicine/ $\mathrm{NaOH}$ buffer, and $\mathrm{MOPS} / \mathrm{NaOH}$ buffer. The initial rate of formaldehyde formation (measured over a 10 min period) was proportional to the concentration of supernatant fraction protein up to at least $80 \mathrm{mg}$ protein $\mathrm{ml}^{-1} ; 50 \mathrm{mg}$ protein $\mathrm{ml}^{-1}$ was routinely used. Hyperbolic curves for increases in activity with increases in concentration of serine (in the presence of $25 \mu \mathrm{M}$-pyridoxal phosphate) and pyridoxal phosphate (with $1.0 \mathrm{~mm}$-serine) were observed. The $V_{\max }$ was $63 \mathrm{nmol}$ formaldehyde produced $\min ^{-1}$ (mg supernatant fraction protein) ${ }^{-1}$. The $K_{\mathrm{m}}$ values for serine and pyridoxal phosphate were $0.14 \mathrm{~mm}$ and $7 \mu \mathrm{M}$, respectively.

Several potential feedback inhibitors or activators of SHMT were tested. A non-saturating concentration of serine $(0.1 \mathrm{mM})$ was used, in the presence of a much higher concentration ( $2 \mathrm{mM}$ ) of each of the potential effectors. The compounds tested were AMP, IMP, GMP, dTMP, AMP + GMP + IMP, AMP + CMP + IMP + histidine, glycine, L-methionine, Lhomocysteine, $S$-adenosyl-L-methionine, $S$-adenosyl-L-homocysteine, L- $\beta$-cyanoalanine, Lhistidine, cysteamine, $\beta$-mercaptoethanol, dithiothreitol, L-alanine, pyruvate, $O$-acetyl-L-serine, adenine, thymine, inosine, guanidine, thymidine and adenosine. These included end-products of the primary metabolic pathways of glycine and the tetrahydrofolate-linked carbon-one pool, as well as $\beta$-cyanoalanine, the end-product of secondary metabolism of glycine. Cyanide was not tested as it inhibits by interaction with pyridoxal phosphate. Of the compounds tested only glycine and cysteine had any effect, each causing $66 \%$ inhibition. With all the other compounds activity was 83 to $104 \%$ of the control value. It is noteworthy that the metabolites of methionine had no effect. The analogues of serine and metabolically related compounds also showed no inhibition except, as mentioned above, cysteine and glycine.

Glycine and cysteine were competitive inhibitors. The $K_{\mathrm{i}}$ value for glycine was $1.3 \mathrm{~mm}$. A similar $K_{\mathrm{i}}$ was found for cysteine.

A range of compounds was added to the growth medium to test their effects on the level of synthesis of SHMT by $C$. violaceum. The carbon and nitrogen source for growth was $10 \mathrm{~mm}-$ glutamate, and the bacteria were harvested $11 \mathrm{~h}$ after inoculation. The following compounds (all at $2 \mathrm{mM}$ ) were tested: glycine, methionine, glycine + methionine, cysteine, histidine, AMP, GMP, IMP, serine, threonine, homocysteine, methionine + glycine + histidine, glycine + 
methionine + AMP or GMP or IMP, AMP + GMP + IMP + cysteine + histidine, glycine + methionine + cysteine or homocysteine, methionine + glycine + AMP + IMP, and GMP + histidine + cysteine. There was no induction or repression of SHMT activity, which was in each case in the range 50 to $68 \mathrm{nmol}$ formaldehyde produced $\mathrm{min}^{-1}$ (mg supernatant fraction protein) ${ }^{-1}$.

\section{Glycine cleavage enzyme}

GCE activity of $C$. violaceum grown on glutamate, glutamate + glycine or glutamate + glycine and methionine was very low. The specific activities were $0.12 \pm 0.02,0.13 \pm 0.02$ and $0.16 \pm 0.04 \mathrm{nmol} \mathrm{min}^{-1}$ (mg protein) ${ }^{-1}$, respectively. GCE activity was located almost entirely in the supernatant fraction.

In order to check that the assay system was working, the experiment was repeated using extracts derived from $E$. coli $\mathrm{K} 12$ grown on $\mathrm{M}-9$ salts containing glucose and $\mathrm{NH}_{4} \mathrm{Cl}$. Inclusion of glycine in the medium caused a 150-fold induction of GCE activity to give a specific activity of $7.5 \mathrm{nmol} \mathrm{min}-1$ (mg protein) $)^{-1}$.

\section{DISCUSSION}

Relatively little is known about the regulation of synthesis and activity of SHMT and the tetrahydrofolate-linked carbon-one metabolism of bacteria (Schirch, 1982). Synthesis of SHMT by wild-type $E$. coli and mutants deficient in the methionine pathway is not repressed by exogenous methionine and only slightly by purines or thymidine (e.g. Meedel \& Pizer, 1974). The intracellular concentration of methionine or $S$-adenosylmethionine probably affects the level of synthesis of SHMT (Greene \& Radovich, 1975). Synthesis of SHMT is repressed in $E$. coli by high concentrations of exogenous glycine or by a mixture of products of the carbon-one pathway (Miller \& Newman, 1974). In Salmonella typhimurium synthesis of SHMT is partially repressed by exogenous methionine and more so by a mixture of serine, glycine, methionine, adenine, guanine and thymine (Stauffer \& Brenchley, 1977). No evidence has been reported for feedback inhibition of SHMT of $E$. coli or $S$. typhimurium, although the SHMT from a facultative methylotroph grown on succinate is stimulated by divalent metals and is competitively inhibited by glycine (O'Connor \& Hanson, 1975).

SHMT of $C$. violaceum is unlike those of the enteric bacteria in that no repression was found on addition of glycine or methionine, or a mixture of products of the carbon-one pathway, to the growth medium. In this organism regulation of synthesis of enzymes associated with the carbonone pool is therefore not at the level of SHMT. The competitive inhibition of SHMT activity of $C$. violaceum by glycine is similar to that found for the facultative methylotroph studied by O'Connor \& Hanson (1975). The competitive inhibition of SHMT activity by cysteine is interesting in that cysteine is also the substrate (with cyanide) for the methionine-sensitive enzyme, $\beta$-cyanoalanine synthase, which causes formation of the secondary metabolite, $\beta$ cyanoalanine (Rodgers \& Knowles, 1978; Rodgers 1981, 1982).

During exponential growth of $E$. coli the cellular demand for glycine is about $40 \%$ less than the requirement for carbon-one units (Dev \& Harvey, 1982). The extra carbon-one units are provided by the activity of GCE as well as SHMT. GCE is inducible by addition of glycine to the growth medium (Meedel \& Pizer, 1974). In contrast to $E$. coli, only very low GCE activity was found in C. violaceum, less than $0.8 \%$ of the SHMT activity. If there is a similar ratio of demand for carbon-one units, glycine and methionine in C. violaceum, and if SHMT is the sole step for provision of carbon-one units, there must be a surplus of glycine formed. This could then be removed as cyanide. Moreover, this could be aggravated during the period when cyanide formation is maximal, i.e. in the idiophase when growth is slowing down, particularly in the presence of exogenous methionine and glycine, where the ratio of demand for carbon-one units and glycine for purines and thymidine is decreasing more rapidly than the demand for amino acids (cf. Harvey \& Dev, 1975). This would then lead to extra synthesis of cyanide and $\beta$ cyanoalanine. 


\section{REFERENCES}

Bauchop, T. \& Elsden, S. R. (1960). The growth of micro-organisms in relation to their energy supply. Journal of General Microbiology 23, 457-469.

Bunch, A. W. \& KNowles, C. J. (1982). Production of the secondary metabolite cyanide by extracts of Chromobacterium violaceum. Journal of General Microbiology 128, 2675-2680.

Castric, P. A. (1977). Glycine metabolism by Pseudomonas aeruginosa: hydrogen cyanide biosynthesis. Journal of Bacteriology 130, 826-831.

CASTRIC, P. A. (1981). The metabolism of hydrogen cyanide by bacteria. In Cyanide in Biology, pp. 233262. Edited by B. Vennesland, E. E. Conn, C. J. Knowles, J. Westley \& F. Wissing. London \& New York: Academic Press.

Castric, P. A., Castric, K. F. \& Meganathan, R. (1981). Factors influencing cyanogenesis in Pseudomonas aeruginosa. In Cyanide in Biology, pp. 263-274. Edited by B. Vennesland, E. E. Conn, C. J. Knowles, J. Westley \& F. Wissing. London \& New York: Academic Press.

Demain, A. L., Kennel, Y. M. \& Aharonowitz, Y. (1979). Carbon catabolite regulation of secondary metabolism. Symposium of the Society for General Microbiology 29, 163-185.

Dev, I. K. \& HaRveY, R. J. (1982). Sources of onecarbon units in the folate pathway of Escherichia coli. Journal of Biological Chemistry 257, 1980-1986.

FOLK, W. \& BERG, P. (1970). Isolation and partial characterization of Escherichia coli mutants with altered glycyl transfer ribonucleic acid synthetases. Journal of Bacteriology 102, 193-203.

GreENE, R. C. \& RADOvich, C. (1975). Role of methionine in the regulation of serine hydroxymethyltransferase in Escherichia coli. Journal of Bacteriology 124, 269-278.

KNowles, C. J. (1976). Microorganisms and cyanide. Bacteriological Reviews 40, 652-680.

KølvRAA, S. (1979). Inhibition of the glycine cleavage system by branched-chain amino acid metabolites. Pediatric Research 13, 889-893.

Lambert, J. L., Ramasamy, J. \& Paukstelis, J. V. (1975). Stable reagents for the colorimetric determination of cyanide by modified König reactions. Analytical Chemistry 47, 916-918.

MALIK, V. S. (1980). Microbial secondary metabolism. Trends in Biochemical Sciences 4, 68-72.

Meedel, T. H. \& Pizer, L. J. (1974). Regulation of one-carbon biosynthesis and utilization in Escherichia coli. Journal of Bacteriology 118, 905-910.

Michaels, R. \& CoRPE, W. A. (1965). Cyanide formation by Chromobacterium violaceum. Journal of Bacteriology 89, 106-112.
Miller, J. H. (1972). Experiments in Molecular Genetics, p. 431. New York: Cold Spring Harbor Laboratory.

Miller, B. A. \& Newman, E. B. (1974). Control of serine transhydroxymethylase synthesis in Escherichia coli K12. Canadian Journal of Microbiology 20, 41-47.

Moore, A. L., Jackson, C., Halliwell, B., Dench, J. E. \& HALL, D. O. (1977). Intramitochondrial localisation of glycine decarboxylase in spinach leaves. Biochemical and Biophysical Research Communications 78, 483-491.

O’Connor, M. L. \& Hanson, R. S. (1975). Serine transhydroxymethylase isozymes from a facultative methylotroph. Journal of Bacteriology 124, 985-996.

RoDGers, P. B. (1981). Cyanide degradation by Chromobacterium violaceum. In Cyanide in Biology, pp. 301-310. Edited by B. Vennesland, E. E. Conn, C. J. Knowles, J. Westley \& F. Wissing. London \& New York: Academic Press.

RodGers, P. B. (1982). Cyanide metabolism and $\beta$ cyanoalanine formation by washed, non-proliferating cultures of Chromobacterium violaceum: studies with radiolabelled cyanide. Journal of General Microbiology 128, 2983-2989.

RoDGers, P. B. \& KNowles, C. J. (1978). Cyanide production and degradation during growth of Chromobacterium violaceum. Journal of General Microbiology 108, 261-267.

Rose, A. H. (1979). Production and industrial importance of secondary products of metabolism. In Economic Microbiology, vol. 3, pp. 1-33. Edited by A. H. Rose. London \& New York: Academic Press.

SCHIRCH, L. (1982). Serine hydroxymethyltransferase. Advances in Enzymology 53, 83-112.

Stauffer, G. B. \& BRENCHLey, J. E. (1977). Influence of methionine biosynthesis on serine transhydroxymethylase regulation in Salmonella typhimurium LT2. Journal of Bacteriology 129, 740-749.

Wissing, F. (1968). Growth curves and pH-optima for cyanide producing bacteria. Physiologia plantarum 21, 589-593.

Wissing, F. \& ANDERSEn, K. A. (1981). The enzymology of cyanide production from glycine by a Pseudomonas species. Solubilization of the enzyme. In Cyanide in Biology, pp. 275-288. Edited by B. Vennesland, E. E. Conn, C. J. Knowles, J. Westley \& F. Wissing. London \& New York: Academic Press.

ZÄHNER, H. (1977). Some aspects of antibiotics research. Angewandte Chemie 16, 687-694. 